\title{
PRE-GERMINATION TREATMENTS OF PARICÁ (Schizolobium amazonicum) SEEDS
}

\author{
TRATAMENTOS PRÉ-GERMINATIVOS EM SEMENTES DE PARICÁ (Schizolobium \\ amazonicum)
}

\author{
Estefânia Martins BARDIVIESSO ${ }^{1}$; Thiago Barbosa BATISTA ${ }^{1}$; \\ Flávio Ferreira da Silva BINOTTI'² Edilson COSTA ${ }^{2}$; Tiago Alexandre da SILVA ${ }^{1}$; \\ Natália de Brito Lima LANNA ${ }^{1}$; Ana Carolina Picinini PETRONILIO ${ }^{1}$ \\ 1. Paulista State University "Júlio de Mesquita Filho" - College of Agricultural Science, Department of Crop Science, Botucatu, SP, \\ Brazil. estefania.bardiviesso@hotmail.com; 2. Mato Grosso do Sul State University, Cassilândia, MS, Brazil.
}

\begin{abstract}
Paricá seeds have dormancy and, even after mechanical scarification, these seeds show slow and uneven germination. Pre-germination treatments can be used to increase seed germination performance. Thus, the aimed to evaluate the physiological potential and initial growth of paricá seeds after pre-germination treatments, using different substances as plant regulators and nutrients, in addition to mechanical scarification. The experimental design was completely randomized, in a $2 \times 7$ factorial scheme, consisting of the following pre-germination treatments: mechanical scarification $(10 \%$ and $50 \%$ of the seed coat) and seed pre-soaking [control-water, $\mathrm{KNO}_{3} 0.2 \%, \mathrm{Ca}\left(\mathrm{NO}_{3}\right)_{2} 0.2 \%$, gibberellin $0.02 \%$, cytokinin $0.02 \%$, and mixture of gibberellin + cytokinin (1:1)] besides a control group without pre-soaking, with four replicates. The study evaluated germination and emergence rates, germination and emergence speed indices, collar diameter, plant height, seedling dry mass, hypocotyl and seedling length, and electrical conductivity. It was observed that pre-soaking the seeds in gibberellin after mechanical scarification at $50 \%$ as a pre-germination treatment resulted in seeds with higher vigor expression and greater initial seedling growth.
\end{abstract}

KEYWORDS: Gibberellin. Cytokinin. Pre-soaking. Mechanical scarification.

\section{INTRODUCTION}

Schizolobium amazonicum (Huber ex Ducke) Barneby, the Brazilian fern tree, locally referred to as paricá, is a forest species of the family Fabaceae (Leguminosae) and subfamily Caesalpinoideae (BARNEBY, 1996). The species has a wide geographical distribution, can be found in the Brazilian states of Amazonas, Pará, Mato Grosso and Rondônia and is indicated for commercial crops, agroforestry systems and reforestation of degraded areas owing to its rapid growth and high commercial value (TAVARES et al., 2013).

The species is propagated by seeds, and seedling production in commercial nurseries depends on factors such as collection, storage and the overcoming of seed dormancy, which can affect seed germination or seedling formation (NEVES; DALCHIAVON; STIELER, 2010).

In nature, paricá seeds have slow and reduced germination, but when subjected to scarification, germination rates rise above $90 \%$ (CRUZ; CARVALHO, 2006; CARVALHO, 2007). This prolonged time to germination is a strong evidence that the seeds of this species are affected by physical or integument dormancy capable of limiting the rapid and uniform germination of the seeds (CRUZ; MARTINS; CARVALHO, 2001). In intact seeds of this species, hydration does not occur even after they are immersed in water for 72 hours (SHIMIZU et al., 2011). Such dormancy, caused by restricted water entry, is typical of the family Leguminosae (PEREZ, 2004), and since they have dehiscent fruits, their seeds have lignified integument thus granting them greater protection (DAMIÃO FILHO; MORO, 2005).

Several methods have been developed to overcome seed dormancy of forest species, such as mechanical and chemical scarification (ALVES et al., 2008). Studies on seeds of $S$. amazonicum (CRUZ; CARVALHO, 2006) and seeds of Zizyphus joazeiro (ALVES et al., 2008) showed that mechanical scarification with sandpaper is efficient for overcoming physical dormancy. In effect, such scarification methods influence the establishment of seedlings and saplings.

Pre-soaking treatments can also help the seeds to express their full physiological potential, especially by the use of plant and/or nutrient regulators, which can be used as a pre-germination treatment, contributing to germination (PRADO NETO et al., 2007; CANESIN et al., 2012). The use of plant regulators can beneficially influence the 
germination process, allowing germination speed and uniformity, besides favoring plant growth. Thus, the aim of this study was to evaluate the effect different intensities of mechanical scarification and pre-soaking treatments with different chemical agents in paricá seeds.

\section{MATERIAL AND METHODS}

Paricá seeds were collected from matrices in the region of Paragominas (Pará-Brazil) with a germination rate equivalent to zero prior to the experiment onset. The experimental design was completely randomized in a $2 \times 7$ factorial scheme, consisting of mechanical scarification $(10 \%$ or $50 \%$ of integument fragmentation) and seed pre-soaking with different chemical agents [, control-water, $\mathrm{KNO}_{3} 0.2 \%, \mathrm{Ca}\left(\mathrm{NO}_{3}\right)_{2} \quad 0.2 \%, \quad 0.02 \%$ gibberellin, $0.02 \%$ cytokinin, and mixture of gibberellin + cytokinin (1:1)] besides a control group without presoaking, with four replicates.

For seed mechanical scarification, an electric sander was used in the opposite direction of the embryonic axis, removing part of the integument (10\% or $50 \%$ of integument fragmentation). For the $10 \%$ scarification, the integument was removed from the lateral upper part of the seeds opposite to the micropyle, and for the $50 \%$ scarification, the integument was removed from one of the lateral ends of the seeds.

Seeds were pre-soaked in deionized water; potassium nitrate - $\mathrm{KNO}_{3} 0.2 \%$; calcium nitrate $\mathrm{Ca}\left(\mathrm{NO}_{3}\right)_{2} 0,2 \%$; gibberellin - $\mathrm{GA}_{3} 0,02 \%$; cytokinin6-benzylamino-purine $0.02 \%$; and mixture of gibberellin + cytokinin $(1: 1)$. The pre-soaking period was selected according to the absorption curve in deionized water, establishing the period of hydration prior to radicle protrusion, which for $10 \%$-scarified seeds was 27 hours and for 50\%scarified seeds, 23 hours.

Seed physiological potential and seedling performance after the pre-germination treatments were evaluated by the methods described below:

Germination rate: performed with 4 replicates of 25 seeds, seeded on paper rolls moistened with deionized water in the ratio of 2.5 times the substrate mass. The paper rolls were put in plastic bags and then placed in a room seed germinator at $25{ }^{\circ} \mathrm{C}$, and photoperiod of 12 hours. The seeds were counted 15 days after experiment onset, considering as germinated the seeds with a radicle $\geq 2 \mathrm{~mm}$ (RAMOS; VARELA; MELO, 2006).

Germination speed index: performed in conjunction with the germination test, with daily counts of the germinated seeds (15 days), calculated according to the formula below, adapted from Maguire (1962): $\mathrm{GSI}=\left(\mathrm{G}_{1} / \mathrm{N}_{1}+\mathrm{G}_{2} / \mathrm{N}_{2}+\ldots+\right.$ $\mathrm{G}_{\mathrm{n}} / \mathrm{N}_{\mathrm{n}}$ ), where: GSI = germination speed index; $G_{1}$, $G_{2}$ e $G_{n}=$ number of seeds with radicle protrusion determined at the first, second ....and last count; $\mathrm{N}_{1}$, $\mathrm{N}_{2}$ e $\mathrm{N}_{\mathrm{n}}=$ number of days from the experiment onset until the first, second ... and last count.

Electrical conductivity: performed by means of the test known as "mass conductivity", with 4 replicates of 10 seeds. For each replicate, seed mass was measured with precision of at least three decimal places, then seed was soaked in a container with $75 \mathrm{~mL}$ of deionized water $(3-5 \mu \mathrm{S}$ $\mathrm{cm}^{-1}$ of conductivity), and kept in a room seed germinator at $25^{\circ} \mathrm{C}$ for 24 hours. After the 24 hour period, the electrical conductivity in the soaking solution was measured using a benchtop conductivity meter. The results were expressed in $\mu \mathrm{S} \mathrm{cm} \mathrm{c}^{-1} \mathrm{~g}^{-1}$ of seeds (VIEIRA; KRZYZANOWSKI, 1999).

Hypocotyl length: performed in the laboratory with 4 replicates of 12 seeds, on germination paper, along two longitudinal lines drawn in the upper third of the paper. The seeds were positioned in a way that the micropyle faced the bottom of the paper. The paper rolls were kept at a constant temperature of $25{ }^{\circ} \mathrm{C}$ in an upright position. After 7 days from experiment onset, hypocotyl length was measured (NAKAGAWA, 1999).

Seedling emergence rate: performed in a greenhouse, using 4 replicates of 25 seeds per treatment, sown at $3 \mathrm{~cm}$ deep in trays with sand. Emerged seedlings were counted after 15 days, considering as emerged those with apparent hypocotyl above soil surface.

Emergence speed index: performed in parallel with the seedling emergence test. The evaluations were performed by counting the number of emerged seedlings (after 15 days) daily. The emergence speed index was calculated according to Maguire (1962) previously described.

Collar diameter, plant height and dry mass: after the seedling emergence test, the plants were measured for collar diameter using a digital caliper, shoot height (from base to apex) using a ruler in centimeter, and seedling dry mass. Additionally, remnants of the seeds that were adhered to the plants were removed. Subsequently, the plants were kept I $n$ a greenhouse with forced air circulation at $65{ }^{\circ} \mathrm{C}$ for 72 hours. The result was expressed in mg plant $^{-1}$.

The data were evaluated through analysis of variance by the F-test for mechanical scarification, 
and by the Tukey test for the pre-soaking factor, at a 0.05 significance level (BANZATTO; KRONKA, 2013).

\section{RESULTS AND DISCUSSION}

Table 1. Effect of the pre-germination treatment on germination (G), germination speed index (GSI), seedling emergence (SE) and emergence speed index (ESI) of S. amazonicum.

\begin{tabular}{|c|c|c|c|c|c|c|c|c|}
\hline \multirow{3}{*}{ Pre-germination treatment } & \multicolumn{8}{|c|}{ Mechanical Scarification } \\
\hline & $10 \%$ & $50 \%$ & $10 \%$ & $50 \%$ & $10 \%$ & $50 \%$ & $10 \%$ & $50 \%$ \\
\hline & G (\%) & & GSI & & SE (\%) & & ESI & \\
\hline Non-soaked - Control & $92 \mathrm{aB}$ & $100 \mathrm{aA}$ & $6.17 \mathrm{Bb}$ & $9.12 \mathrm{dA}$ & $98 \mathrm{aA}$ & $98 \mathrm{aA}$ & $2.30 \mathrm{bB}$ & $2.74 \mathrm{bcA}$ \\
\hline Water & $98 \mathrm{aA}$ & $95 \mathrm{aA}$ & $21.43 \mathrm{aA}$ & $22.62 \mathrm{aA}$ & $95 \mathrm{aA}$ & $95 \mathrm{aA}$ & $2.54 \mathrm{abB}$ & $3.17 \mathrm{abcA}$ \\
\hline Gibberellin & $93 \mathrm{aA}$ & $92 \mathrm{aA}$ & $21.20 \mathrm{aA}$ & $22.29 \mathrm{aA}$ & $96 \mathrm{aA}$ & $98 \mathrm{aA}$ & $2.89 \mathrm{aB}$ & $3.27 \mathrm{abA}$ \\
\hline Cytokinin & $96 \mathrm{aA}$ & $76 \mathrm{bB}$ & $19.40 \mathrm{aA}$ & $12.62 \mathrm{cB}$ & $19 \mathrm{cB}$ & $38 \mathrm{bA}$ & $0.34 \mathrm{~dB}$ & $0.94 \mathrm{dA}$ \\
\hline Giberelin + Cytokinin & $95 \mathrm{aA}$ & $91 \mathrm{aA}$ & $20.01 \mathrm{aA}$ & $18.66 \mathrm{bA}$ & $75 \mathrm{bA}$ & $50 \mathrm{bB}$ & $1.55 \mathrm{cA}$ & $1.10 \mathrm{~dB}$ \\
\hline Potassium Nitrate & $99 \mathrm{aA}$ & $95 \mathrm{aA}$ & $20.25 \mathrm{aB}$ & $22.54 \mathrm{aA}$ & $96 \mathrm{aA}$ & $88 \mathrm{aA}$ & $3.07 \mathrm{aA}$ & $2.68 \mathrm{cB}$ \\
\hline Calcium Nitrate & $96 \mathrm{aA}$ & $98 \mathrm{aA}$ & $21.41 \mathrm{aA}$ & $22.95 \mathrm{aA}$ & $89 \mathrm{aA}$ & $98 \mathrm{aA}$ & $2.16 \mathrm{bB}$ & $3.40 \mathrm{aA}$ \\
\hline $\mathrm{CV} \%$ & 4.57 & & 6.85 & & 9,81 & & 10.94 & \\
\hline
\end{tabular}

Means followed by different lowercase letters within a column and different uppercase letters within a row differ statistically from each other by the Tukey test and by the F-test at a 0.05 significance level, respectively. $\mathrm{CV}=$ coefficient of variation.

Germination rate did not differ statistically between the pre-germination treatments of the $10 \%$ scarified seeds. In the non-soaked seeds (control group), the $50 \%$-scarification of seed coat resulted in higher germination. Cytokinin as a pre-soaking chemical agent interfered negatively in germination when applied to the $50 \%$-scarified seeds (Table 1).

Mechanical scarification with emery paper on seeds of $S$. amazonicum resulted in overcoming dormancy with increased germination rates (CRUZ; CARVALHO, 2006), similar to chemical scarification using sulfuric acid $\left(\mathrm{H}_{2} \mathrm{SO}_{4}\right)$ for 60 minutes (CRUZ; CARVALHO; QUEIROZ, 2007). The present study verified that the germination rate of $S$. amazonicum seeds increased as the scarification intensity increased, evidencing the need for seed coat scarification, as can be seen in the literature. This increase in the percentage (50\%) of integument scarification allowed better hydration of the seed tissues, also facilitating radicle protrusion, which resulted in an increase in the seed germination rate and seedling emergence speed (Table 1). This improvement in germination, with scarification at a higher intensity, is in line with the findings of Santos et al. (2004), who recommended coat scarification on both sides of chichá (Sterculia foetida L.) seeds, without pre-soaking, to overcome dormancy.

In $50 \%$-scarified seeds, the highest speed germination indices were verified in pre-soaking treatments using water, gibberellin, potassium nitrate and calcium nitrate. In $10 \%$-scarified seeds this index was increased with all the chemical agents used for pre-soaking (Table 1).

The increase in the paricá germination speed using the chemical agent gibberellin is in agreement with the results of Guimarães et al. (2010) in seeds of Thlaspi caerulescens, because gibberellin is involved in the synthesis of enzymes that degrade the reserves of the seed that will be mobilized to the embryonic axis to initiate the activity in the root apical meristem for its growth, thus allowing radicle protrusion. Other positive effects on germination from the application of this plant regulator have been reported, such as the increase in germination rate and speed index in kiwi seeds [Actinidia deliciosa (A. Chev.) E. F. Liang et A.R. Ferguson] (YNOUE; ONO; MARCHI, 1999), pomegranate seeds (Punica granatum L.) (TAKATA et al., 2014) and biribá seeds [Annona (Rollinia) mucosa Jacq. Baill.] (CAMPOS et al., 2015).

In paricá seeds, the gibberellin used for presoaking $\left(\mathrm{GA}_{3}\right)$ did not influence germination rate, 
however it increased the germination speed index. It can be inferred that the use of $\mathrm{GA}_{3}$ in pre-soaking accelerated the events that trigger the rupture of the reserve tissue, leading to a faster growth of the embryo axis, which is an advantage for these seeds and results in an increase in the germination speed index.

Shimizu et al. (2011) emphasize that germination depends mainly on tissue hydration, as it promotes resumption of the seed metabolism. The mechanical scarification at $50 \%$ intensity contributed to rapid germination and seedling emergence due to greater availability of water for the paricá seed tissues, resulting in rapid seed soaking. This accelerates the onset of hydrolytic enzyme activities and the respiratory process for energy production in the form of ATP and carbon skeletons required for the other biochemical processes that occur during the germination process, considering that the intact integument of this species prevents the entry of water.

Pre-germination treatments and scarification intensities did not differ statistically for the total emergence rates of the seedlings, except for treatments with cytokinins (cytokinin, and gibberellin + cytokinin), for both $10 \%$ and $50 \%$ scarification intensities, which resulted in a decrease in the seedling emergence rate. Additionally, in treatments with cytokinin, a negative effect was observed for the variables of total germination rate, germination speed index and emergence speed index.

Cytokinins are involved in the germination process of some species, and may be related to membrane permeability (VIEIRA; CASTRO, 2001). However, in the present study, the results affected all variables and can be explained by the high concentration of the commercial product used. It is very likely that such high concentration caused physiological disturbances during germination, impairing even seedling formation (Table 2).

The $50 \%$ scarification combined with the calcium nitrate pre-soaking treatment, as well as the $10 \%$ scarification combined with potassium nitrate, which did not differ from water and $\mathrm{GA}_{3}$ treatments, favored a higher ESI (Table 1). Higher expression of seed vigor facilitated emergence (SHIMIZU et al., 2011) through mechanical scarification associated with chemical agents. Similar results were also reported by Lopes et al. (2009) for embu seeds (Spondias tuberosa Arruda), Santarém and
Aquila (1995) for pau-fava seeds [Senna macranthera (DC. ex Collad.) H. S. Irwin Barneby], Oliveira et al. (2008) for fava d'anta seeds (Dimorphandra mollis Benth) and Melo et al. (2011) for faveira seeds (Parkia spp).

Dutra et al. (2012) state that the higher the emergence speed, the shorter the time the seeds will be exposed to adverse conditions such as pests and diseases, in addition to reducing the seedling permanence time in nurseries. Therefore, pregermination treatments, as those carried out in this study, allow obtaining higher-quality seedlings in a shorter period of time.

Seeds pre-soaked with calcium nitrate submitted to $50 \%$ scarification yielded positive values of seed germination rate, GSI, ESI and seedling emergence rate (Table 1). Calcium has a role in cell division and elongation, and this function may explain the effects on the physiological quality of the seeds and the initial growth of the seedlings described in this study.

Interaction between the factors studied were observed for hypocotyl length, plant height and seedling dry mass. The use of gibberellin in seed pre-soaking yielded seedlings with higher hypocotyl length and plant height, regardless of scarification. Gibberellin also promoted higher plant height combined with $50 \%$ scarification (Table 2), similar to the results of Campos et al. (2015) for biribá seeds [Annona (Rollinia) mucosa Jacq. Baill.]; and contrary to the findings of Takata et al. (2014) using gibberellin in the pre-germination treatment of pomegranate seeds (Punica granatum L.).

In line with the results verified in the present study, Prado Neto et al. (2007), studying different concentrations of gibberellic acid and commercial plant stimulant in genipap seeds (Genipa americana) through pre-soaking processes, found that the presence of gibberellic acid yielded seedlings with larger root and shoot length.

The highest plant growth (with gibberellin) (Table 2) observed was due to the fact that gibberellin stimulates cell division and elongation, favoring the formation of new cells. The $\mathrm{GA}_{3}$ bioregulator used in this study, and as per Stenzel, Murata and Neves (2003), provides stimuli for the synthesis of enzymes, which will digest reserves of the reserve tissue of the seed, resulting in amino acids, nucleic acids and simple sugars, which will be absorbed for the growth of the embryo. 
Table 2. Effect of the pre-germination treatment on hypocotyl length (HL), plant height (P.H.) and seedling dry mass (SDM) of S. amazonicum.

\begin{tabular}{|c|c|c|c|c|c|c|}
\hline \multirow{3}{*}{ Pre-germination treatment } & \multicolumn{6}{|c|}{ Mechanical Scarification } \\
\hline & \multirow{2}{*}{\multicolumn{2}{|c|}{$\begin{array}{l}10 \% \\
\text { HL }(\mathrm{cm})\end{array}$}} & \multirow{2}{*}{$\begin{array}{l}10 \% \\
\mathrm{PH}(\mathrm{cm})\end{array}$} & $50 \%$ & $10 \%$ & $50 \%$ \\
\hline & & & & \multicolumn{3}{|c|}{ SDM (mg plant $\left.{ }^{-1}\right)$} \\
\hline Non-soaked - Control & $3.31 \mathrm{~dB}$ & $4.30 \mathrm{cA}$ & $25.30 \mathrm{cA}$ & $25.64 \mathrm{bA}$ & $204,69 \mathrm{bA}$ & $222,13 \mathrm{cA}$ \\
\hline Water & $5.75 \mathrm{bA}$ & $5.60 \mathrm{bA}$ & $27.25 \mathrm{bcA}$ & $26.22 \mathrm{bA}$ & $234,90 \mathrm{aA}$ & $241,62 \mathrm{bcA}$ \\
\hline Gibberellin & $7.55 \mathrm{aA}$ & $7.59 \mathrm{aA}$ & $32.92 \mathrm{aB}$ & $35.27 \mathrm{aA}$ & $262,53 \mathrm{aA}$ & $279,59 \mathrm{aA}$ \\
\hline Cytokinin & $1.34 \mathrm{eA}$ & $1.10 \mathrm{dA}$ & $10.56 \mathrm{dA}$ & $6.85 \mathrm{~dB}$ & $169,30 \mathrm{cA}$ & $174,39 \mathrm{dA}$ \\
\hline Giberelin + Cytokinin & $1.93 \mathrm{eB}$ & $3.43 \mathrm{cA}$ & $11.71 \mathrm{dA}$ & $10.17 \mathrm{cA}$ & $169,63 \mathrm{cA}$ & $145,42 \mathrm{Db}$ \\
\hline Potassium Nitrate & $4.51 \mathrm{cB}$ & $5.69 \mathrm{bA}$ & $27.03 \mathrm{bcA}$ & $25.87 \mathrm{bA}$ & $251,17 \mathrm{aA}$ & $230,99 \mathrm{bcB}$ \\
\hline Calcium Nitrate & $4.40 \mathrm{cB}$ & $5.64 \mathrm{bA}$ & $28.30 \mathrm{Ba}$ & $26.80 \mathrm{bA}$ & $241,33 \mathrm{aA}$ & $256,63 \mathrm{abA}$ \\
\hline $\mathrm{CV} \%$ & 9.84 & & 4.75 & & 6.17 & \\
\hline
\end{tabular}

The hypocotyl is extremely necessary for dicotyledons, mainly because it elevates the cotyledons and epicotyl to the soil surface. It is associated with the seedling ability to emerge and overcome the seeding depth barrier and the soil layer. Therefore, when using gibberellin in the presoaking treatment, the seedlings showed greater emergence capacity, which can be confirmed by the ESI data (Table 1), showing that the use of $\mathrm{GA}_{3}$ in the pre-germination treatment increased the speed emergence index of the paricá seeds.

Seed pre-soaking, except for agents cytokinin and gibberellin + cytokinin, increased the dry mass of the paricá seedlings originated from $10 \%$-scarified seeds. The highest mass values of seedlings originating from $50 \%$-scarified seeds were observed for treatments with gibberellin and with calcium nitrate (Table 2). The use of cytokinin in seed hydration altered the hormonal balance, negatively interfering with the physiological processes during germination and plant growth (evidenced by hypocotyl length, plant height and dry mass). According to Vieira et al. (2010), cytokinins may promote or inhibit root growth, depending on the plant and the concentration; and high concentrations may inhibit dry mass growth and root elongation.

Separate influence from the factors studied was observed for electrical conductivity and plant collar diameter. Higher leaching levels, measured by electrical conductivity, were observed for $10 \%$ scarified seeds (Table 3).
The use of pre-germination treatments led to a reduction in the leaching values, as measured by the electrical conductivity test. Water, gibberellin, cytokinin and gibberellin + cytokinin obtained lower conductivity because seed hydration led to damage repair and membrane organization, leaving them more selective and thus reducing the amount of exudates removed during the process of seed soaking.

The different intensities of scarification did not statistically influence plant collar diameter, with greater response observed for the pre-germination treatment with cytokinin (Table 3 ).

The use of cytokinin as a pre-germination treatment had a negative influence on seed germination, seedling height and emergence, as lower results were found in comparison to other pregermination treatments (Table 1 and 2). This result can be explained by the morphological change occurring in the hypocotyl region, which is of great importance for the emergence of this species (Table 2). Apart from the hypocotyl change, there was no adequate development of secondary roots and true leaves. The use of cytokinin provided seedlings with smaller hypocotyls, but with a larger collar diameter, and therefore did not provide adequate "hook" formation to pull the cotyledons above the substrate (Table 2). The concentration of cytokinin used in the pre-germination treatment changed the hypocotyl region morphologically, impairing germination and emergence of the paricá seeds, yielding abnormal plants. 
Table 3. Effect of the pre-germination treatment on electrical conductivity $\left(\mu \mathrm{Sm}^{-1} \mathrm{~g}^{-1}\right)$ and collar diameter $(\mathrm{mm})$ in $S$. amazonicum.

\begin{tabular}{lll}
\hline Treatments & $\begin{array}{l}\text { Electrical Conductivity } \mu \mathrm{S} \mathrm{cm} \mathrm{cm}^{-} \\
{ }^{1} \mathrm{~g}^{-1}\end{array}$ & $\begin{array}{l}\text { Collar Diameter } \\
(\mathrm{mm})\end{array}$ \\
\hline Scarification & ${ }^{\mathrm{M}} 7.73 \mathrm{~b}$ & ${ }^{\mathrm{M}} 3.73 \mathrm{a}$ \\
$50 \%$ & $8.93 \mathrm{a}$ & $3.70 \mathrm{a}$ \\
$10 \%$ & $21.74 \mathrm{a}$ & $3.26 \mathrm{c}$ \\
\hline Pre-germination treatment & $4.41 \mathrm{c}$ & $2.99 \mathrm{c}$ \\
Non-soaked - Control & $4.68 \mathrm{c}$ & $2.97 \mathrm{c}$ \\
Water & $5.32 \mathrm{c}$ & $5.63 \mathrm{a}$ \\
Gibberellin & $5.20 \mathrm{c}$ & $5.26 \mathrm{~b}$ \\
Cytokinin & $8.45 \mathrm{~b}$ & $2.93 \mathrm{c}$ \\
Giberelin + Cytokinin & $8.52 \mathrm{~b}$ & $2.96 \mathrm{c}$ \\
Potassium Nitrate & 14.65 & 6.34 \\
Calcium Nitrate &
\end{tabular}

CV (\%)

14.65

6.34

${ }^{\mathrm{M}}$ Means followed by different lowercase letters within a column differ statistically from each other by the Tukey test and by the F-test at a 0.05 significance level, respectively. $\mathrm{CV}=$ coefficient of variation.

This study verified that the use of $50 \%$ scarification allowed the seeds to hydrate the tissues faster, thus increasing the speed of germination and emergence, in addition to plant initial growth. Seed hydration with water leads to a higher germination speed. In order to increase the plant initial growth (length of the hypocotyl and height), the use of gibberellin for physiological conditioning is recommended.

Finally, 6-benzylamino-purine cytokinin at the concentration of $0.02 \%$ used in the pregermination treatment is not recommended because it caused a reduction in seed performance, in addition to inadequate growth. It is worth noting that there is a need for studies using other concentrations of cytokinin in order to increase knowledge of this agent for pre-soaking treatments.

\section{CONCLUSION}

Seed pre-soaking with gibberellin after mechanical scarification at $50 \%$ intensity as a pregermination treatment is recommended to obtain seeds with higher vigor expression and greater initial seedling growth.

RESUMO: Sementes de paricá apresentam dormência e após superada pela escarificação mecânica, as sementes apresentam germinação lenta e desuniforme. Tratamentos pré-germinativos podem ser utilizados para incrementar a performance de germinação de sementes. Assim, o objetivo foi avaliar o potencial fisiológico de sementes, crescimento inicial de Paricá após tratamentos pré-germinativos, utilizando diferentes substâncias como reguladores vegetais e nutrientes, além da intensidade da escarificação mecânica. $\mathrm{O}$ delineamento experimental empregado foi o inteiramente casualizado, em esquema fatorial $2 \times 7$, constituído pelos tratamentos pré-germinativos: escarificação mecânica $(10 \%$ e $50 \%$ do tegumento) e pré-embebição das sementes [controleágua, $\mathrm{KNO}_{3} 0,2 \%, \mathrm{Ca}\left(\mathrm{NO}_{3}\right)_{2} 0,2 \%$, giberelina $0,02 \%$, citocinina $0,02 \%$, e a mistura da solução de giberelina + citocinina (1:1)] além de um grupo controle sem pré-embebição, com quatro repetições. Avaliou-se a porcentagem de germinação e emergência, índice de velocidade de germinação e emergência, diâmetro, altura e fitomassa seca de plantas, comprimento de plântulas e hipocótilo e condutividade elétrica. A pré-embebição das sementes com giberelina após escarificação mecânica de 50\% como tratamento pré-germinativo é recomendado para obtenção de sementes com maior expressão de vigor e crescimento inicial de plântulas.

PALAVRAS-CHAVE: Giberelina. Citocinina. Pré-embebição. Escarificação mecânica. 


\section{REFERENCES}

ALVES, E. U.; BRAGA JÚNIOR, J. M.; BRUNO, R. L. A.; OLIVEIRA, A. P.; CARDOSO, E. A.; ALVES, A. U.; ALVES, A. U.; SILVA, K. B. Métodos para quebra de dormência de unidade de dispersão de Zizyphus joazeiro Mart. (Rhamnaceae). Revista Árvore, Viçosa, v. 32, n. 3, p.407-415, 2008.

http://dx.doi.org/10.1590/S0100-67622008000300003

BARNEBY, R. C. Neotropical Fabales at NY: asides and oversights. Brittonia, v. 48, p.174-187, 1996. https://doi.org/10.2307/2807811.

BANZATTO, D. A.; KRONKA, S. N. Experimentação Agrícola. 4. ed. Jaboticabal: Funep/Unesp, 2013. 237 p.

CAMPOS, L. F. C.; ABREU, C. M.; GUIMARÃES, R. N.; SELEGUINI, A. Escarificação e ácido giberélico na emergência e crescimento de plântulas de biribá. Ciência Rural, Santa Maria, v. 45, n. 10, p.1748-1754, 2015. http://dx.doi.org/10.1590/0103-8478cr20140249

CANESIN, A.; MARTINS, J. M. D. T.; SCALON, S. P. Q.; MASETTO, T. E. Bioestimulante no vigor de sementes e plântulas de faveiro (Dimorphandra mollis Benth.). Cerne, Lavras, v. 18, n. 2, p. 309-315, 2012. http://dx.doi.org/10.1590/S0104-77602012000200016

CARVALHO, P. E. R. Paricá: Schizolobium amazonicum. Colombo, PR. EMBRAPA. 2007. 8p. (Circular Técnica 142).

CRUZ, E. D.; MARTINS, F. O.; CARVALHO, J. E. U. Biometria de frutos e sementes e germinação de Jatobá-curuba (Hymenaea intermedia Ducke, Leguminosae - Caesalpinioideae). Revista Brasileira de Botânica, São Paulo, v. 24, n. 1, p.161-165, 2001. http://dx.doi.org/10.1590/S0100-84042001000200005

CRUZ, E. D.; CARVALHO, J. E. U. Methods of overcoming dormancy in Schizolobium amazonicum Huber ex Ducke (Leguminosae - Caesalpinioideae) seeds. Revista Brasileira de Sementes, Londrina, vol. 28, n. 3, p. 108-115, 2006. http://dx.doi.org/10.1590/S0101-31222006000300016

CRUZ, E. D.; CARVALHO, J. E. U.; QUEIROZ, R. J. B. Scarification with sulphuric acid of Schizolobium amazonicum Huber ex Ducke seeds - FABACEAE. Scientia Agricola, Piracicaba, v. 64, n. 3, p. 308-313, 2007. http://dx.doi.org/10.1590/S0103-90162007000300017

DAMIÃO-FILHO, C. F.; MÔRO, F. V. Morfologia Vegetal. 2.ed. Jaboticabal: FUNEP, 2005. 172p.

DUTRA, T. R.; MASSAD, M. D.; SARMENTO, M. F. Q.; OLIVEIRA, J. C. Emergência e crescimento inicial da canafístula em diferentes substratos e métodos de superação de dormência. Revista Caatinga, Mossoró, v. 25, n. 2, p. 65-71, 2012. https://periodicos.ufersa.edu.br/index.php/caatinga/article/view/2243/pdf

GUIMARÃES, M. A.; VIDIGAL, D. S.; LOUREIRO, M. E.; DIAS, D. C. F. S.; GUIMARÃES, A. R. Influência de temperatura, luz e giberelina na germinação de sementes de Thlaspi caerulescens J. Presl \& C. Presl (Brassicaceae). Revista Ceres, Viçosa, v. 57, n. 3, p. 372-376, 2010. http://dx.doi.org/10.1590/S0034737X2010000300013

LOPES, P. S. N.; MAGALHÃES, H. M.; GOMES, J. G.; BRANDÃO JÚNIOR, D. S.; ARAÚJO, V. D. Superação de sementes de umbuzeiro (Spondias tuberosa, Arr. Câm.) utilizando diferentes métodos. Revista Brasileira de Fruticultura, Jaboticabal, v. 31, n. 3, p. 872-880, 2009. http://dx.doi.org/10.1590/S010029452009000300034

MAGUIRE, J. D. Speed of germination aid in selection and evaluation for seedling and vigour. Crop Science, Madison, v. 2, n. 2, p. 176-177, 1962. http://dx.doi.org/10.2135/cropsci1962.0011183X000200020033x 
MELO, M. G. G.; MENDONÇA, M. S.; NAZÁRIO, P.; MENDES, M. A. S. Superação de dormência em três espécies de Parkia spp. Revista Brasileira de Sementes, Londrina, v. 33, n. 3, p. 533-542, 2011.

http://dx.doi.org/10.1590/S0101-31222011000300016

NAKAGAWA, J. Testes de vigor baseados na avaliação das plântulas. In: KRYZANOWSKI, F. C.; VIEIRA, R. D.; FRANÇA NETO, J. B. (Ed.). Vigor de sementes: conceitos e testes. Londrina: ABRATES, 1999, p.12,21 .

NEVES, G.; DALCHIAVON, F. C.; STIELER, M. C. Superação da dormência em sementes de Schilobuim amazonicum. UNICências, Cuiabá, v. 14, n. 2, p. 271-285, 2010.

http://www.pgsskroton.com.br/seer/index.php/uniciencias/article/view/779

OLIVEIRA, D. M.; NUNES, Y. R. F.; ROCHA, E. A.; BRAGA, R. F.; PIMENTA, M. A. S; VELOSO, M. D. M. Potencial germinativo de sementes de fava-d'anta (Dimorphandra mollis Benth. - FABACEAE:

MIMOSOIDEAE) sob diferentes procedências, datas de coleta e tratamentos de escarificação. Revista Árvore, Viçosa, v. 32, n. 6, p. 1001-1009, 2008. http://dx.doi.org/10.1590/S0100-67622008000600005

PEREZ, S. C. J. G. A. Envoltórios. In: FERREIRA, A. G.; BORGHETTI, F. (Ed.). Germinação: do básico ao aplicado. Porto Alegre: Artmed, 2004, p.125-134.

PRADO NETO, M.; DANTAS, A. C. V. L.; VIEIRA, E. L.; ALMEIDA, V. O. Germinação de sementes de jenipapeiro submetidas à pré-embebição em regulador e estimulante vegetal. Ciência e Agrotecnologia, Lavras, v. 31, n. 3, p. 693-698, 2007. http://www.scielo.br/pdf/cagro/v31n3/a14v31n3. https://doi.org/10.1590/S1413-70542007000300014

RAMOS, M. B.; VARELA, V. P.; MELO, M. F. F. Influência da temperatura e da água sobre a germinação de sementes de paricá (Schizolobium amazonicum Huber ex Ducke - Leguminosae-Caesalpinioideae). Revista Brasileira de semente, Pelotas, v. 28, n. 1, p. 163-168, 2006. http://dx.doi.org/10.1590/S010131222006000100023

SANTARÉM, E. R.; AQUILA, M. E. A. Influência de métodos de superação de dormência e do armazenamento na germinação de sementes de Senna macranthera (Colladon) Irwin \& Barneby (Leguminosae). Revista Brasileira de Sementes, Brasília, v. 17, n. 2, p. 205-209, 1995.

https://doi.org/10.17801/0101-3122/rbs.v17n2p205-209

SANTOS, T. O.; MORAIS, T. G. O.; MATOS, V. P. Escarificação mecânica em sementes de chihá ( Sterculia foetida L.). Revista Árvore, Viçosa, v. 28, n. 1, p. 1-6, 2004.

https://doi.org/10.1590/S010067622004000100001

SHIMIZU, E. S. C.; PINHEIRO, H. A; COSTA, M. A.; SANTOS FILHO, B. G. Aspectos fisiológicos da germinação e da qualidade de plântulas de Schizolobium amazonicum em resposta à escarificação das sementes em lixa e água quente. Revista Árvore, Viçosa, v. 35, n. 4, p. 791-800, 2011. http://dx.doi.org/10.1590/S010067622011000500004

STENZEL, N. M. C.; MURATA, I. M.; NEVES, C. S. V. J. Superação de dormência em sementes de atemóia e fruta-do-conde. Revista Brasileira de Fruticultura, Jaboticabal, v. 25, n. 2, p. 305-308, 2003. http://dx.doi.org/10.1590/S0100-29452003000200031

TAVARES, L. S.; SCARAMUZZA, W. L. M. P.; WEBER, O. L. S.; VALADÃO, F. C. A.; MAAS, K. D. B. Lodo do curtimento e sua influência na produção de mudas de paricá (Schizolobium amazonicum) e nas propriedades químicas do solo. Ciência Florestal, Santa Maria, v. 23, n. 3, p. 357-368, 2013.

https://doi.org/10.5902/1980509810547 
TAKATA, W.; SILVA, W. G.; CORSATO, J. M.; FERREIRA, G. Germinação de sementes de romãzeiras (Punica granatum l.) de acordo com a concentração de giberelina. Revista Brasileira de Fruticultura, Jaboticabal, v. 36, n. 1, p. 254-260, 2014. http://dx.doi.org/10.1590/0100-2945-269/13

VIEIRA, R. D.; KRYZANOWSKI, F. C. Teste de condutividade elétrica. In: KRYZANOWSKI, F. C.; VIEIRA, R. D.; FRANÇA NETO, J. B. (Ed.). Vigor de sementes: conceitos e testes. Londrina: ABRATES, 1999, p. 1-26.

VIEIRA, E. L.; CASTRO, P. R. C. Ação de bioestimulante na germinação de sementes, vigor de plântulas, crescimento radicular e produtividade de soja. Revista Brasileira de Sementes, Londrina, v. 23, n. 2, p. 222228, 2001. http://dx.doi.org/10.17801/0101-3122/rbs.v23n2p222-228

VIEIRA, E. L.; SOUZA, G. S.; SANTOS, A. R.; SILVA, J.S. Manual de fisiologia vegetal. São Luis: Edufma, 2010. 230 p.

YNOUE, C. K.; ONO, E. O.; MARCHI, L. O. S. Efeito do $\mathrm{GA}_{3}$ na germinação de sementes de kiwi (Actinidia chinensis Planch.). Scientia Agricola, Piracicaba, v. 56, n. 1, p. 9-12, 1999. http://dx.doi.org/10.1590/S010390161999000100002 